\title{
THE EFFECT OF STRATIFIED DOSES OF CURRY LEAF EXTRACT (MURRAYA KOENIGII) ON TOTAL CHOLESTEROL AND TRIGLYCERIDES IN MALE SPRAGUE-DAWLEY RATS INDUCED BY HIGH FAT FEED
}

\author{
Muhammad Iqbal Reynaldi ${ }^{1 *}$, Santoso $^{2}$, Kusmiyati Tjahjono $^{2}$ \\ ${ }^{1}$ Undergraduate Program, Faculty of Medicine, Diponegoro University, Semarang, Indonesia \\ ${ }^{2}$ Department of Medical Biology and Biochemistry, Faculty of Medicine, Diponegoro University, Semarang, Indonesia \\ * Corresponding author, E-mail: iqbalreynaldi14@gmail.com
}

\begin{abstract}
Background: High levels of total cholesterol and triglycerides in the blood can cause atherosclerosis. Curry leaves are often used by the society to reduce total cholesterol and triglyceride levels in the blood, but no studies have examined the effective dosage of curry leaf extract to reduce total cholesterol and triglyceride levels. Aim: This study aimed to determine the effect of giving curry leaf extract (Murraya koenigii) on serum cholesterol and triglyceride levels of male Sprague-Dawley rats induced by high fat feed. Methods: This study was a true experimental study with a pre-post test with randomized controlled group design. The subjects of the study were male Sprague-Dawley rats induced by high-fat feed then given curry leaf extract at a dose of $200 \mathrm{mg} / \mathrm{KgBW}, 300$ $\mathrm{mg} / \mathrm{KgBW}$, and $400 \mathrm{mg} / \mathrm{KgBW}$ for 10 days. Cholesterol and triglyceride levels were measured by enzymatic methods. The data were analyzed using paired t test, Wilcoxon test, repeated Anova test to analyze differences between groups which was then followed by post hoc bonferoni and One Way Anova to analyze the differences in cholesterol and triglyceride levels between groups. Results: There was no significant difference in total cholesterol levels between before and after given the curry leaf extract at a dose of $200 \mathrm{mg} / \mathrm{KgBW}, 300 \mathrm{mg} / \mathrm{KgBW}$, and $400 \mathrm{mg} / \mathrm{KgBW}$ ( $\mathrm{p}=0.641$ for the P1 group, $\mathrm{p}=0.385$ for the P2 group and $\mathrm{p}=0.398$ for the group. group P3). In contrast to triglyceride levels, there were differences in triglyceride levels before and after administration of curry leaf extract at a dose of $300 \mathrm{mg} / \mathrm{kgBW}(\mathrm{p}=0.012)$, while the other groups were not significant. Conclusions: The 10 days of stratified dose curry leaves (M. Koenigii) in this study could not reduce cholesterol level and triglyceride level.
\end{abstract}

Keywords: Curry leaf extract; Dyslipidemia; Total Cholesterol; Triglyceride

\section{INTRODUCTION}

Dyslipidemia is a lipid metabolism disorder characterized by an increase in total cholesterol levels, triglyceride levels, LowDensity Lipoprotein (LDL) cholesterol levels and low High-Density Lipoprotein (HDL) cholesterol levels. ${ }^{1}$ Indonesian National Basic Health Research (RISKESDAS) 2013 data shows that there were $35.9 \%$ of Indonesia's population aged $\geq$ 15 years with total cholesterol levels $\geq 200 \mathrm{mg}$ / dlf. The RISKESDAS data also showed that $15.9 \%$ of the population aged $\geq 15$ years had an LDL proportion of $\geq 190 \mathrm{mg} / \mathrm{dl}, 22.9 \%$ had HDL levels less than $40 \mathrm{mg} / \mathrm{dl}$, and $11.9 \%$ with triglyceride levels $\geq 500 \mathrm{mg} / \mathrm{dl}^{2}$

Dyslipidemia is a risk factor for cardiovascular disease. ${ }^{1}$ Dyslipidemia causes atherosclerosis which in turn has the potential to cause coronary heart disease (CHD) and stroke. The prevalence of coronary heart disease in Indonesia in 2013 was $0.5 \%$ of the total population or an estimated 883,447 people. World Health Organization (WHO) data in 2011 showed that cardiovascular disease was the leading cause of death worldwide. Of the 57 million population deaths in the world, 17.3 million $(30 \%)$ deaths were caused by cardiovascular disease, especially heart attacks 7.3 million (12.8\%) and stroke 6.2 million (10.8\%). It is estimated that by 2030, 23.6 million people worldwide will die from cardiovascular disease. ${ }^{2.3}$

The blood lipid profile is a detectable component of lipids in the blood. Lipid profile consists of total cholesterol, triglycerides, LDL cholesterol and HDL cholesterol in the blood. Total cholesterol is a combination of the amount of LDL cholesterol, HDL cholesterol, and triglycerides in every deciliter of blood. Total cholesterol is influenced by the increase or decrease of LDL, HDL, and triglycerides. Triglycerides are the result of the conversion of most of the fat in the body which is carried in the 
bloodstream and stored in the tissues. Triglycerides are released from the tissues into the bloodstream to be used as energy when needed. Triglyceride levels can exceed normal when the intake of triglycerides from food exceeds the required amount. High levels of total cholesterol and triglycerides can lead to thickening of the walls of blood vessels so that you are at risk of coronary heart disease and stroke. ${ }^{4}$

Recently, a therapy to treat dyslipidemia has been developed, namely by means of the Mediterranean diet and administration of synthetic drugs. The principles of this Mediterranean diet are low in saturated fat ( $9-10 \%$ of daily energy needs) and high in unsaturated fats, especially omega 3 fatty acids, and high in fiber, which is 27 - 37 grams per day. Synthetic drugs used to treat dyslipidemia are HMG-CoA reductase inhibitors (statin group). Statins are cholesterol-lowering drugs that are most effective at lowering LDL cholesterol levels, statins can also lower triglyceride levels and increase HDL cholesterol. Statins work by inhibiting the action of HMGCoA reductase and increasing the regulation of LDL cholesterol receptors, thereby increasing the clearance of LDL cholesterol in the liver. Side effects of statin such as hyperglycemia and peripheral neuropathy cause many people do not want to take statin drugs, so that alternatives are needed in the form of traditional medicines to treat dyslipidemia such as the curry leaf, but that does not mean the use of traditional medicines is safe without side effects. Improper use of traditional medicines can cause unwanted side effects. $^{2}$

Curry leaves (Murraya koenigii) or commonly known as curry leaves are one of the most abundant plants in Indonesia. These leaves are usually used as ingredients in spices and traditional medicines that are effective for curing dizziness, stomach aches, diarrhea, flu, rheumatism, wound medicine, and diabetes. ${ }^{7}$ Based on the results of phytochemical tests from samples of curry leaves, it contents alkaloids, flavonoids, terpenoids , saponins, phytosterols, phenolics, glycosides, tannins, carbohydrates, proteins and amino acids. Some of its compounds such as flavonoids have the potential to act as inhibitors of the HMG-CoA reductase enzyme so that decreases cholesterol synthesis. Alkaloids can also inhibit the activity of the pancreatic lipase enzyme so that the absorption of monoglycerides and fatty acids decreases and does not cause fat accumulation. ${ }^{7,8}$ Saponins can lower cholesterol by binding and preventing absorption of cholesterol by forming complex bonds that do not dissolve with cholesterol so that cholesterol cannot be absorbed by the intestine whereas tannins are able to inhibit the absorption of fat in the intestine by reacting with mucosal proteins and intestinal epithelial cells. Tannins can deposit mucosal proteins on the surface of the small intestine, thereby reducing the effectiveness of cholesterol absorption. ${ }^{9,10,11}$

Study in 2012 proved that administration of curry leaf extract with a true experimental posttest only with controlled group research design at a dose of $300 \mathrm{mg} / \mathrm{KgBW}$ in obese rats and receiving intraperitoneal injection of $1 \mathrm{~g} / \mathrm{KgBW}$ glucose can reduce body weight, total cholesterol, triglycerides, and blood glucose levels. ${ }^{12} \mathrm{We}$ were interested in knowing the effect of ethanol extract administration from curry leaves with stratified doses (200 mg / KgBW, $300 \mathrm{mg} /$ $\mathrm{KgBW}$, and $400 \mathrm{mg} / \mathrm{kgBW}$ ) against SpragueDawley rats induced by high-fat feed to find the optimal dose that can reduce levels of triglycerides and total cholesterol in rats.

\section{METHOD}

This study was a true experimental study with a pre-test and post-test controlled group design. Adaptation was carried out for 7 days with standard feed and drinking water ad libitum. Furthermore, the samples were divided into 4 groups each - 7 rats randomly, namely the control group, P1, P2, and P3. The four groups were given high-fat feed in the form of cow brains as much as $2 \mathrm{ml}$ for 10 days. Then each group was given different treatments for 10 days, namely the control group (standard feed), P1 (standard feed + curry leaf extract $200 \mathrm{mg} / \mathrm{KgBW}$ ), P2 (standard feed $+300 \mathrm{mg} / \mathrm{KgBW}$ curry leaf extract), and P3 (standard feed + curry leaf extract $400 \mathrm{mg} /$ $\mathrm{KgBW}$ ). Pretest and posttest were conducted to measure total cholesterol and triglyceride levels. 
The sample of this study used was 28 normal male Sprague-Dawley rats, 8 weeks old, and 150-250 grams of body weight obtained from the biology laboratory of the Faculty of Mathematics and Natural Sciences (FMIPA) Semarang State University. Purposive sampling was carried out and for group determination, randomization was carried out.

Curry leaves were extracted using 96\% ethanol solvent by maceration method. Blood samples were taken from the retroorbital plexus and then checked for total cholesterol levels by the CHOD-PAP method and triglycerides using the GPO-PAP method.

Data analysis

The collected data were analyzed by repeated Anova test followed by post-hoc Bonferoni.

Ethical Clearance

Ethical approval for this study was obtaine from Komisis Etik Penelitian Kesehatan (KEPK) Fakultas Kedokteran Universitas
Diponegoro, Semarang ( No. 50/EC/H/FKUNDIP/VI/2020)

\section{RESULT}

The average body weight of rats in this study did not differ significantly between groups ( $p=0.576$ ). During the study, the rats were in good health and none died until the end of the study.

Table 1. The Mean Body Weight of Rats

\begin{tabular}{ccc}
\hline Groups & $\begin{array}{c}\text { Mean Body Weight } \pm \text { SD } \\
\text { (gram) }\end{array}$ & p-value \\
\hline $\mathrm{K}(\mathrm{n}=7)$ & $188,5 \pm 22,7$ & \\
$\mathrm{P} 1(\mathrm{n}=7)$ & $192 \pm 27,7$ & 0,576 \\
P2 $(\mathrm{n}=7)$ & $178,4 \pm 18,2$ & \\
P3 $(\mathrm{n}=7)$ & $194,2 \pm 22,1$ & \\
\hline
\end{tabular}

There was no significant difference in total cholesterol levels before and after curry leaf extract administration to each group ( $\mathrm{p}>0.05)$ and between groups $(p=0.076)$.

Table 2. Cholesterol levels in Control and Treatment Groups

\begin{tabular}{ccccc}
\hline Groups & $\begin{array}{c}\text { Before Treatment } \\
\text { Median } \\
(\text { Min-Max) }(\mathbf{m g} / \mathbf{d L})\end{array}$ & $\begin{array}{c}\text { After Treatment } \\
\text { Mean } \pm \text { SD } \\
(\mathbf{m g} / \mathbf{d L})\end{array}$ & $\begin{array}{c}\text { p-value } \\
\text { K }(\mathrm{n}=7)\end{array}$ & $\begin{array}{c}\text { Difference in Total } \\
\text { Cholesterol Level } \\
\text { Mean } \pm \text { SD }(\mathbf{m g} / \mathbf{d L})\end{array}$ \\
P1 $(\mathrm{n}=7)$ & $116,36(113,39-160,86)$ & $115,75 \pm 6,97$ & 0,410 & $-15,05 \pm 14,86$ \\
P2 $(\mathrm{n}=7)$ & $130,04(116,99-141,73)$ & $128,21 \pm 5,73$ & 0,641 & $7,72 \pm 14,96$ \\
P3 $(\mathrm{n}=7)$ & $107,99(103,71-131,16)$ & $118,84 \pm 16,60$ & 0,385 & $-3,68 \pm 10,34$ \\
\hline
\end{tabular}

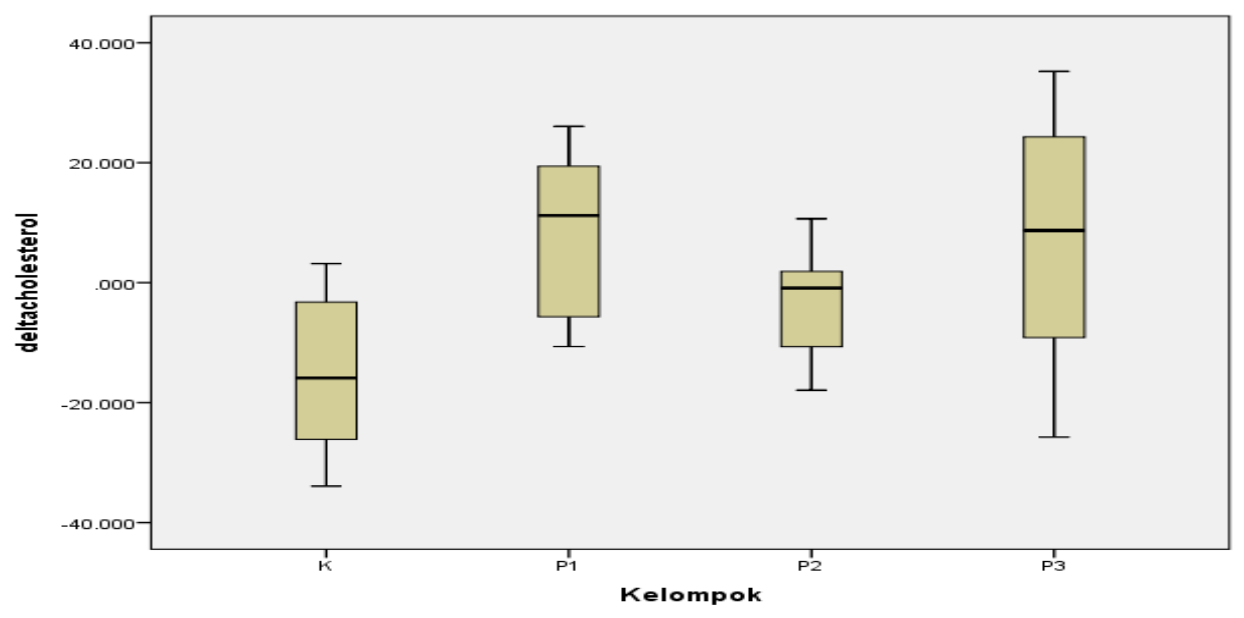

Figure 1. Distribution Graph of the Difference in Total Cholesterol Levels 
There is no significant difference in triglyceride levels before and after curry leaf extract administration except in the $\mathrm{P} 2$ group $(p=$ 0.012).

Tabel 3. Triglyceride levels in Control and Treatment Groups

\begin{tabular}{lccccc}
\hline Groups & $\begin{array}{c}\text { Before Treatment } \\
\text { Mean } \pm \text { SD }(\mathbf{m g} / \mathbf{d L})\end{array}$ & $\begin{array}{c}\text { After Treatment } \\
\text { Mean } \pm \text { SD }(\mathbf{m g} / \mathbf{d L})\end{array}$ & p-value & $\begin{array}{c}\text { Difference in Triglyceride Level } \\
\text { Mean } \pm \text { SD }(\mathbf{m g} / \mathbf{d L})\end{array}$ & $\begin{array}{c}\mathbf{p}- \\
\text { value }\end{array}$ \\
\hline $\mathrm{K}(\mathrm{n}=7)$ & $138,99 \pm 12,64$ & $142,74 \pm 3,67$ & 0,888 & $3,75 \pm 13,40$ & \\
$\mathrm{P} 1(\mathrm{n}=7)$ & $145,15 \pm 7,03$ & $153,01 \pm 2,65$ & 0,823 & $7,86 \pm 7,24$ & \\
P2 $(\mathrm{n}=7)$ & $140,90 \pm 2,43$ & $150,87 \pm 6,64$ & $\left.0,012^{*}\right)$ & $9,96 \pm 8,83$ & 0,591 \\
$\mathrm{P} 3(\mathrm{n}=7)$ & $137,55 \pm 1,37$ & $142,85 \pm 5,35$ & 0,051 & $5,30 \pm 4,97$ & \\
\hline
\end{tabular}

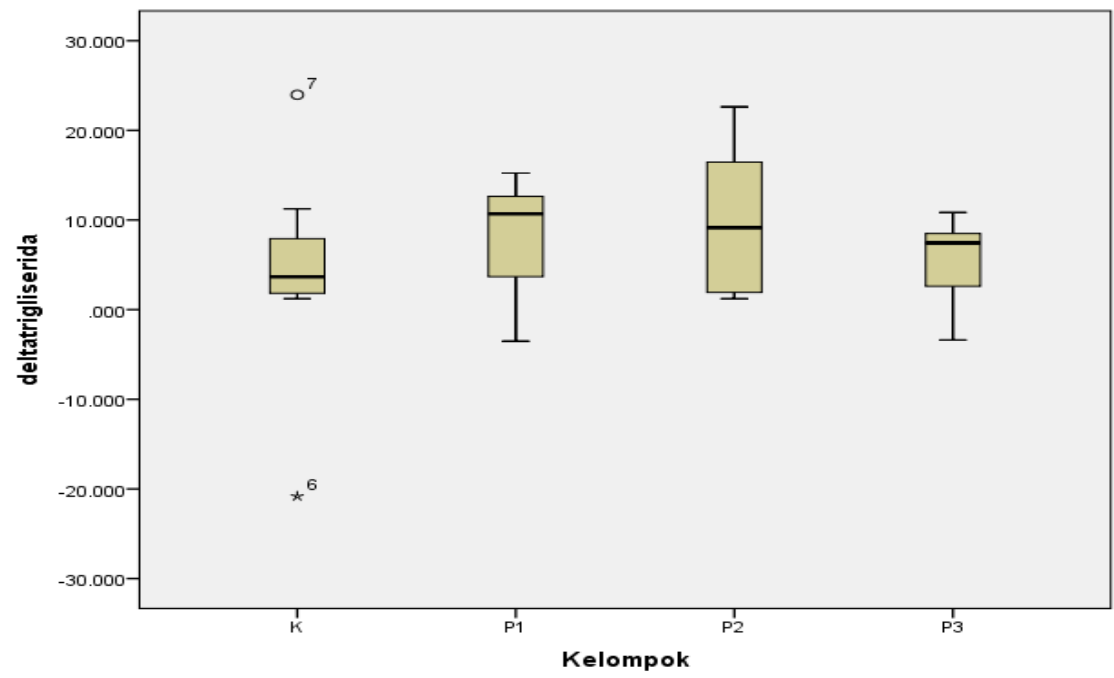

Figure 2. Distribution Graph of the Difference in Triglyceride Levels

\section{DISCUSSION}

\section{Effect of curry leaf extract administration on} total cholesterol

Curry leaf extract contains flavonoids, alkaloids, tannins, and saponins. ${ }^{8}$ The compounds in this extract can reduce total cholesterol levels in the blood because these compounds can affect fat metabolism. Flavonoids work by inhibiting the HMG-CoA reductase enzyme so that cholesterol synthesis decreases. Alkaloids work by inhibiting the activity of the pancreatic lipase enzyme, thereby increasing fat secretion through feces. Tannins can deposit mucosal proteins on the surface of the small intestine, thereby reducing cholesterol absorption. ${ }^{13}$ Saponins work by forming bonds with bile acids to form micelles so that cholesterol cannot be absorbed by the intestine. $^{14}$
Based on the study of Tembhurne et al, Murraya koenigii leaf extract administration at a dose of $300 \mathrm{mg} / \mathrm{KgBW}$ for 15 days to male Wistar rats can significantly reduce cholesterol levels. ${ }^{12}$ In contrast to the results of Tembhurne et al's study, in this study, the comparison of cholesterol levels before and after the extract curry leaves administration of each group showed no significant difference. The high-fat feed used in this study was cow's brain, whereas in previous studies used vanspati ghee, cow ghee, corn oil, lard oil, and peanut oil. ${ }^{12}$ Cholesterol content in 100 grams of cow brain is $3100 \mathrm{mg}$, much higher than in previous studies, 100 grams of cow ghee which only contains $256 \mathrm{mg}$ of cholesterol, and vanspati ghee also does not contain cholesterol. ${ }^{15}$ The duration of curry leaf extract administration in this study was 5 days shorter than previous studies so that there can be differences in the 
accumulated doses contained in the rats' bodies where the longer the duration of administration, the higher the cholesterol-lowering effect. In this study, the comparison of total cholesterol levels before and after curry leaf extract administration showed that there were no significant results.

In Xie et al's study, curry leaf extract administration for 10 days at a dose of $80 \mathrm{mg} /$ $\mathrm{KgBW}$ by intraperitoneal injection in $o b / o b$ rats could significantly reduce cholesterol levels. ${ }^{16}$ Although the duration of curry leaf extract was the same as this study, the results were different because the way of administering curry leaf extract is different. In previous studies it was given by intraperitoneal injection, whereas in this study it was given orally. In addition, in this study obese rats were used but not high-fat feed was induced, while in this study the rats were given high-fat feed in the form of cow brains.

Another factor that causes an increase in cholesterol levels after the intervention period is stress. Stress in research subjects was caused by administering beef brains and curry leaf extracts through the enteral administration as well as the process of taking blood from the orbital plexus. During stress the mammals add extra energy in the form of fatty acids and glucose to the blood. These fatty acids and glucose are obtained from the breakdown of triacylglycerols from adipose tissue by catecholamine-stimulated lipases. This process is induced by cortisol. The increase in fatty acids and cortisol results in insulin sensitivity and increases the synthesis of triacylglycerol and apo-B in the liver. The secretion of VLDL by the liver also increases, this VLDL will be converted into LDL which transports cholesterol in the blood. In addition, stress can reduce the cleaning of lipids in the blood, causing cholesterol buildup in the blood. It is also possible that the increase in cholesterol levels after the intervention period was due to the metabolic effects of the bovine brain suspension that continued after the intervention period. High cholesterol intake can reduce the rate of lipid clearance, so that cholesterol levels remain high. 17,18

Duration of curry leaf extract administration which was not long enough so that it could not reduce the total cholesterol levels of male Sprague-Dawley rats and no phytochemical test was carried out on curry leaf extract so that it could not know the levels of the compounds contained in the curry leaf extract used.

Effect of curry leaf extract administration on triglyceride levels

Curry leaf extract contains flavonoids, alkaloids, tannins, and saponins. ${ }^{8}$ Flavonoids can increase the activity of the lipoprotein lipase enzyme to hydrolyze triglycerides into free fatty acids so that triglyceride levels in the body can decrease. Alkaloids can reduce the activity of the pancreatic lipase enzyme so that it can reduce triglycerides that are absorbed from the small intestine. ${ }^{13} \quad$ Saponins have antihypertriglyceridemic activity by increasing the excretion of triglycerides through feces. ${ }^{14}$ Research by Tembhurne et al. proved that curry leaf extract administration at a dose of $300 \mathrm{mg} /$ $\mathrm{KgBW}$ for 15 days in male wistar rats significantly reduced triglyceride levels. ${ }^{12}$

In this study, the comparison of triglyceride levels before and after curry leaf extract administration showed significant results in the P2 group, while in the other groups there were no significant results.

In the study of Kesari et al, curry leaf extract administration at a dose of $300 \mathrm{mg} /$ $\mathrm{KgBW}$ to streptozotocin-induced rats showed a decrease in triglyceride levels by $31.7 \% .{ }^{19}$ In this study, the comparison of triglyceride levels before and after curry leaf extract administration was not in accordance with previous studies. This is because there are differences in the high fat feed used and the shorter duration of administration of curry leaf extract. In addition, high-fat diets induce triglyceride levels higher than cholesterol levels in rat serum, this is in accordance with the process of lipid metabolism in the body where excessive calories from food are converted to triglycerides before being converted into other types of cholesterol. ${ }^{20}$ At the beginning of metabolism, triglyceride levels were obtained that were higher than total cholesterol levels. Another factor that causes an increase in triglyceride levels after the intervention period is stress. Stress in research subjects was caused by administering 
beef brains and curry leaf extracts through the enteral route as well as the process of taking blood from the orbital plexus. During stress, mammals release the adrenaline hormones, which is a hormone produced by the adrenal glands and some neurons. This hormones make the heart beat fast and the cortisol hormone will increase glucose levels in the blood. This level of glucose in the blood should be used as an energy source, but under stressful conditions, glucose will be used to make triglycerides. If the stress lasts a long time, the production of triglycerides will increase which results: ${ }^{17}$

It was found that the duration of curry leaf extract administration which was not long enough to reduce the triglyceride levels of male SpragueDawley rats and no phytochemical test was carried out on the curry leaf extract.

\section{CONCLUSION}

There was no significant effect on 10 days administration of stratified dose of curry leaf extract on total cholesterol and triglycerides of male Sprague-Dawley rats induced by high-fat feed.

\section{REFERENCES}

1. Mozaffarian D, Wilson PW, Kannel WB. Beyond established and novel risk factors: lifestyle risk factors for cardiovascular disease. Circulation. 2008;117(23):3031-8.

2. Badan penelitian dan pengembangan kesehatan kementrian kesehatan RI. Laporan Nasional Riset Kesehatan Dasar (RISKESDAS). 2013.

3. Mahalle N, Garg MK, Naik SS, Kulkarni MV. Study of pattern of dyslipidemia and its correlation with cardiovascular risk factors in patients with proven coronary artery disease. Indian J Endocrinol Metab. 2014;18(1):48-55.

4. Botham KM, Mayes PA. 2014. Oksidasi Asam Lemak: Ketogenesis dalam Murray RK, Granner DK, Mayes PA, Rodwell VW. Biokimia Harper. Edisi 29. Jakarta: EGC. 239-45

5. Tjay TH, Rahardja K. Obat-obat Penting: Khasiat, Penggunaan dan Efek
Sampingnya. Edisi 6. PT Elex Media Komputindo. Jakarta. 2007. 570-3

6. Golomb BA, Evans MA. Statin adverse effects: a review of the literature and evidence for a mitochondrial mechanism. Am J Cardiovasc Drugs. 2008;8(6):373-418

7. Ajay S, Rahul S, Sumit G, Paras M, Mishra A. Comprehensive review: Murraya koenigii Linn. Asian J Pharm anf Life Sci. 2011;1(4):417-25.

8. Baskaran C, Bai VR, Kanimozhi D. Screening for Antimicrobial Activity and Phytochemical Analysis of Various Leaf Extract of Murraya koenigii. Interinational Journal of Research in Ayurveda and Pharmacy. 2011;2(6): 1807-10.

9. Vinarova L, Vinarov $\mathrm{Z}$, Atanasov V, Pantcheva I, Tcholakova S, Denkov N, et al. Lowering of cholesterol bioaccessibility and serum concentrations by saponins: In vitro and in vivo studies. Food Funct. 2015;6(2):501-12.

10. Ekananda N. Bay leaf in dyslipidemia therapy. J Majority. 2015;4(4):64-9

11. Rahayu T. Blood cholesterol Degree of White Rat (Rattus Norvegicus L) After Getting Kombucha Fluid PerOral.Universitas Muhammadiyah Surakarta.Jurnal Penelitian Sains dan Teknologi.2005;6(2): 85-100

12. Tembhurne SV, Sakarkar DM. Anti-obesity and hypoglycemic effect of ethanolic extract of Murraya koenigii (L) leaves in high fatty diet rats. Asian Pacific Journal of Tropical Disease. 2012;2(1):166-8

13. Dalimartha S. 36 Resep tumbuhan obat untuk menurunkan kolesterol. Surabaya: Penebar Swadaya. 2005. 36

14. Elekofehinti OO, Adanlawo IG, Fakoya A. The Effect of Saponin from Solanum anguivi Lam. Fruit on Serum Lipid and Oxidative Stress in Hepatocyte of Diabetic Rats. Rev Bras PI Med. 2013;88:56-61

15. United States Department of Agriculture (USDA). Beef, raw, brain, variety meats and by Product. [Internet]. USDA. 2020 [cited 14 August 2020]. Available from : 
https://ndb.nal.usda.gov/ndb/search/list?qlo okup $=13320$

16. Xie. JT, Chang. WT, Wang. CZ, Mehendale SR, Li. J, et al. Curry Leaf (Murraya koenigii Spreng.) Reduces Blood Cholesterol and Glucose Levels in ob/ob Mice. The American Journal of Chinese Medicine.2006;34(2): 279-284

17. Steptoe A and Brydon L. Associations Between Acute Lipid Stres Responses and Fasting Lipid Levels 3 Years Later. Health Phsychology.2005;4(6):601-7

18. Merchant AT, et al. Interrelation of saturated fat, trans fat, alcohol intake, and subclinical atherosclerosis. Am J Clin Nutr. 2008; 87:168-74

19. Kesari AN, Kesari S, Singh SK, Gupta RK, Watal G. Studies on the glycemic and lipidemic effect of Murraya koenigii in experimental animals. Journal of Ethnopharmacology. 2007;112(2): 305-11

20. Suyatna FD. 2016. Hipolipidemik dalam Gunawan SG. Farmakologi dan Terapi. Departemen Farmakologi dan Terapeutik Fakultas Kedokteran Universitas Indonesia. Edisi 6. Jakarta: Badan Penerbit. 381-3 